\title{
Response of leaf functional traits of woody plants in central Guizhou to degraded karst soil characteristics
}

\author{
Qi Wang ${ }^{1}$, Li Rong ${ }^{1}$, Mengjie Wang ${ }^{1}$, Tianmu Ye ${ }^{1}$, Tingting Li $^{1}$, Wensong Yang ${ }^{1}$, and \\ Xuan $\mathrm{Li}^{1}$ \\ ${ }^{1}$ Guizhou Normal University
}

July 20, 2021

\begin{abstract}
1.In this study, the dominant woody plants in different degraded background plots in Puding, Guizhou Province were selected as the research objects. Six leaf functional traits(LT, LA, SLA, LDMC, LTD, Chlc) were measured to analyze the effects of soil characteristics on the leaf functional traits of vegetation in the region. 2. We observed that under the degraded environment of karst area, the plant leaves tended to increase, with the most significant change in the returned land; There were significant differences in plant traits under burning,burning felling and returning farmland, with the largest change range of LA, LTD and SLA, which could reach $121.90 \%, 118.08 \%$ and $86.00 \%$ respectively in the corresponding sample plots. 3.In the degraded plots, the leaf traits were significantly different among tree, shrub and liana species. In general, the interspecific variation of shrub and liana species was higher than that of tree species, and the community was in the early and middle stage of succession. 4.Soil properties under different degradation background were quite different,and there was a significant correlation between soil properties and vegetation leaf functional properties. Soil depth, soil nutrients and soil humidity were the key soil characteristic factors of plant leaf functional properties. 5.The results showed that the leaf traits of plant in degraded area showed large LA,small LT, low SLA and LTD, high LDMC and low Chlc, which tended to develop drought character combination. This paper reveals the internal differentiation succession law of degraded karst secondary forest in central Guizhou and provides scientific basis for the management and biodiversity protection of karst secondary forest.
\end{abstract}

\section{Hosted file}

Response_of_leaf_functional_traits_of_woody_plants_in_central_Guizhou_to_degraded_karst_soil_characteri available at https://authorea.com/users/426577/articles/531038-response-of-leaf-functionaltraits-of-woody-plants-in-central-guizhou-to-degraded-karst-soil-characteristics

\section{Hosted file}

Title Page.docx available at https://authorea.com/users/426577/articles/531038-responseof-leaf-functional-traits-of-woody-plants-in-central-guizhou-to-degraded-karst-soilcharacteristics 